\title{
PELATIHAN E-LEARNING MENGGUNAKAN GOOGLE CLASSROOM BAGI GURU MA RADEN FATAH PRAMBANAN
}

\author{
Shoffan Saifullah ${ }^{1}$, Bagus Muhammad Akbar ${ }^{2}$ \\ 1,2 Jurusan Teknik Informatika, Universitas Pembangunan Nasional Veteran Yogyakarta \\ Jalan Babarsari 2 Yogyakarta \\ 1e-mail: shoffans@upnyk.ac.id
}

\begin{abstract}
Abstrak
Pendidikan adalah proses untuk meningkatkan kecerdasan siswa. Proses ini menggunakan kegiatan pelatihan dan pengajaran. Seiring dengan perkembangan teknologi dan komunikasi, proses pelatihan dan pembelajaran menggunakan berbagai metode, salah satunya adalah e-learning. Prosesnya menggunakan internet, yang dapat diakses dan diproses kapan saja dan di mana saja. Proses ini mendukung kebijakan Kementerian Pendidikan dan Kebudayaan Indonesia terkait proses pembelajaran dan mendeka belajar. Proses ini dapat meningkatkan pendidikan aktif, terencana, dan efektif. Selain itu, inovasi layanan dan pembelajaran meningkat sehingga tidak hanya menggunakan pembelajaran konvensional. Tujuan dari pengabdian masyarakat ini adalah untuk melatih para guru di MA Raden Fatah dalam mengimplementasikan e-learning menggunakan Google Classroom. Metode pelaksanaannya menggunakan teori dan praktik. Hasil dari proses pelatihan dapat memberikan inovasi pembelajaran online dengan Google Classroom, dan kemampuan guru untuk mengimplementasikannya dapat meningkatkan proses belajar mandiri. Para guru dapat melakukan pembelajaran dengan kelas virtual mengikuti kondisi pembelajaran di kelas. Kelas yang dibangun dengan Google Classroom dapat digunakan untuk berbagi materi, memberikan tugas, kuis, menetapkan nilai, dan menjadwalkan kegiatan. Selain itu, proses video conference menyesuaikan jadwal di classroom dan calendar dan kalender menggunakan meet.
\end{abstract}

Kata kunci: e-learning, google classroom, inovasi pembelajaran, merdeka belajar

\begin{abstract}
Education is a process to improve student intelligence. This process uses training and teaching activities. Along with the development of technology and communication, the process of training and learning using various methods, one of which is e-learning. The process uses the internet, which can be accessed and processed anytime, anywhere. This process supports the policy of the Indonesian Ministry of Education and Culture regarding the process of learning and free learning. This process can enhance active, planned, and effective education. Besides, service and learning innovation increase so that it does not only use conventional learning. The purpose of this community service is to train teachers at MA Raden Fatah in implementing e-learning using Google Classroom. The method uses theory and practice. The results of the training process can provide online learning innovation with Google Classroom, and the ability of teachers to implement it can improve the independent learning process. The teachers can do learning with virtual classes following the conditions of learning in the classroom. Classes built with Google classroom can be used to share material, provide assignments, quizzes, assign grades, and schedule activities. Besides, the video conference process is following the schedule in the Classroom and Calendar using Meet.
\end{abstract}

Keywords: e-learning, google classroom, learning innovation, free learning 


\section{PENDAHULUAN}

Pendidikan adalah sebuah proses untuk meningkatkan kecerdasan seseorang (Maunah, 2009). Sehingga pendidikan merupakan sesuatu hal yang pokok dan wajib bagi setiap orang di dunia ini (Montolalu, 2015). Indonesia merupakan negara yang sedang meningkatkan kompetensi belajar yang direlevansikan dengan dunia nyata. Mentri Pendidikan dan Kebudayaan RI, Nadiem Makarim memberikan pidato dalam peringatan hari guru nasional yang menegaskan mengenai perubahan dalam pembelajaran. Perubahan mengenai kondisi pembelajaran yang lebih berinovasi dan tidak serta merta di kelas, nunggu instruksi, diajarkan semua materi (Makarim, 2019). Pendidikan tidak terpaku pada ruang dan waktu, artinya pendidikan dapat dilakukan dimanapun dan kapanpun (Kristiana, 2014).

Peningkatan metode pembelajaran (Irawan, Susanti, \& Triyanto, 2015) dalam pendidikan menjadi hal yang harus diupdate seiring dengan perkembangan teknologi informasi dan komunikasi. Proses pembelajaran yang semula hanya dilakukan melalui kegiatan pelatihan dan pengajaran konvensional di dalam kelas (Husna \& Pinem, 2011), mampu meningkat dengan penerapan e-learning (Setiawan, Nurlaela, Muslim, \& Yundra, 2019). Proses pembelajaran berbasis teknologi internet yang memberikan kebebasan akses dan pembelajaran yang interaktif dapat menunjang kemampuan siswa dalam mendapat pengetahuan yang lebih banyak dan pemanfaatan positif dari teknologi itu sendiri.

E-learning merupakan salah satu hal yang mendukung kebijakan Menteri Pendidikan dan Kebudayaan Indonesia dalam inovasi pembelajaran di sekolahan dan mampu memberikan kontribusi bebas dan aktif dalam belajar. Peningkatan kompetensi dibidang teknologi ini sangat penting karena setiap saat teknologi akan semakin pesat berkembang (Wijaya, Sudjimat, \& Nyoto, 2016; Gultom, 2019). Apabila tidak mampu memanfaatkan teknologi maka kedepannya akan tertinggal (Lestari \& Sujarwo, 2018) dan tidak tahu apa-apa.

Pembelajaran ini memberikan pembelajaran yang lebih efektif (Efendi \& Utami, 2019). Selain itu, e-learning ini memungkinkan memberikan layanan yang lebih baik dan menginovasi kepada siswa sehingga tidak terpaku pada 
pembelajaran konvensional. E-learning yang diterapkan yaitu menggunakan Google Classroom. Google classroom merupakan platform e-learning yang disediakan oleh google secara gratis. Platform ini akan membantu guru dan siswa dalam melakukan pembelajaran dengan kelas virtual sesuai dengan kondisi pembelajaran dikelas. Kelas yang dibangun dengan google classroom dapat digunakan untuk membagi materi, memberikan tugas, kuis, dan pemberian nilainya, serta jadwal kegiatan. Hal ini memudahkan dalam proses pembelajaran yang tidak serta merta dilakukan di dalam kelas.

MA Raden Fatah Prambanan merupakan sebuah sekolah swasta yang sedang berkembang. Dalam perkembangannya perlu adanya penerapan teknologi yang mampu memberikan inovasi khususnya dalam bidang pengajaran dan pembelajaran. Salah satu inovasi yang akan dicapai adanya e-learning. Saat ini, para guru yang mengajar masih terasa awam dengan penggunaan elearning. Ada beberapa saja yang hanya sekadar tau dan tidak menggunakan, dan lainya adanya tidak mengetahui untuk menggunakannya. Hal ini menjadi acuan kenapa pengabdian ini menjadi penting untuk melatih para guru di sekolah tersebut. Selain itu, adanya program pemerintah mengenai Mendeka Belajar (kebijakan dari Mendikbud) menjadi celah dalam pengembangan dan inovasi dalam pembelajaran.

Inovasi dalam bidang pendidikan, khususnya pembelajaran dan pengajaran dapat memanfaatkan teknologi yang saat ini sudah sangat pesat. Salah satu yang dapat diimplementasikan adalah Google Classroom. Classroom ini merupakan platform yang disediakan google dengan kemudahan akses dan gratis. Sehingga ketika dilakukan pelatihan tidak membutuhkan banyak biaya, lebih efektif dan efisien. Ini adalah solusi yang ditawarkan tim pengabdi yang basisnya adalah bidang teknologi. Tim pengabdi merupakan dosen yang bergerak di bidang informatika, yang mengedepankan teknologi dalam peningkatan kualitas dalam setiap kegiatan. Dalam pengabdian ini, tujuan yang diharapkan adalah Para Guru dapat mengimplementasikan e-learning dalam proses belajar mengajar. Platform e-learning yang digunakan adalah Google Classroom. Akses guru yang dapat membuat kelas virtual dengan memberikan materi pembelajaran dengan video 
maupaun presentasi, pemberian tugas dan kuis, memantau progres pembelajaran, dan menjadwalkan kegiatan secara runtut dan terencana. Selain itu, ketika proses pertemuan juga dapat menerapkan video conference (sesekali) sebagai tahapan tatap muka dalam pembelajaran secara virtual. Pengabdian ini diharapkan dapat memberikan manfaat kepada para guru dalam mempermudah proses belajar mengajar yang lebih efektif dan efisien. Selain itu, update inovasi pemanfaatan teknologi yang dapat memberikan kontribusi dalam menjalankan kewajibannya untuk menerapkan kebijakan Mendikbud (Merdeka Belajar).

\section{METODE}

Pengabdian masyarakat ini dilakukan untuk memberikan pelatihan Google Classroom dalam pembelajaran yang dilakukan guru di sekolah. Pengabdian ini dilakukan di Madrasah Aliyah (MA) Raden Fatah Prambanan Yogyakarta. Metode yang digunakan adalah observasi dan wawancara langsung dengan pihak sekolah untuk proses awal sebelum melakukan kegiatan pengabdian masyarakat. Adapun kegiatan utama yang dilakukan dalam proses pengabdian masyarakat adalah pelatihan menggunakan metode penyampaian materi, domonstrasi, diskusi dan implementasi secara langsung oleh para peserta. Kegiatan ini diikuti oleh semua guru yang ada di MA Raden Fatah Prambanan. Peserta berjumlah 13 Guru dengan perwakilan bidang masing-masing kelompok IPA dan IPS serta Umum. Kegiatan ini dilaksanakan di Lab. Komputer dengan fasilitas diantaranya adalah komputer/laptop, jaringan, dan LCD untuk proses pembelajarannya.

Tahapan Utama dalam pengabdian ini adalah persiapan, pelaksanaan dan evaluasi. Tahapan persiapan dilakukan dengan menyiapkan peralatan (sarana dan prasarana) dan peserta. Peralatan menggunakan komputer/laptop yang ada di Lab. Komputer MA Raden Fatah Prambanan yang terkoneksi dengan internet. Selain itu, para peserta membawa smartphone untuk proses pelatihan tambahannya. Kemudian tahapan selanjutnya adalah penyampaian materi e-learning dan demo mengenai penggunan Google Classroom. Pada akhir tahapan adalah evaluasi dari kegiatan yang dilakukan peserta dalam mengelola Google Classroom. 
Materi yang disampaikan mengenai dasar dari e-learning dan Google Classroom untuk inovasi pembelajaran secara online. Tahapan ke-2 dilakukan dengan tahapan sebagai Gambar 1.

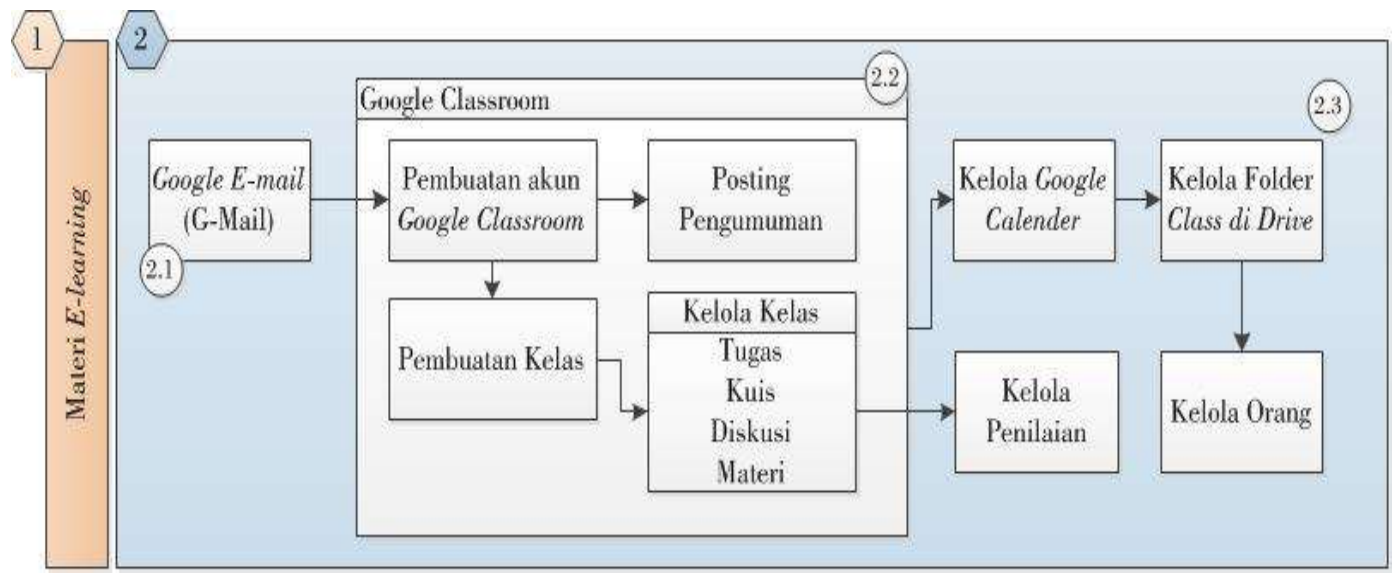

Gambar 1. Tahapan kegiatan yang dilakukan pada saat Pengabdian Masyarakat

Penyampaian materi dan demo secara detail mengenai e-learning dan Google Classroom at dilakukan dengan tahapan-tahapan seperti pada Gambar 1 . E-learning dengan menggunakan Google Classroom harus menggunakan akun GMail, sehingga setiap peserta harus memiliki G-Mail. Akun ini akan digunakan untuk membuat dan mengelola Google Classroom. Google Classroom dapat digunakan dengan langkah awal pembuatan Google Classroom berdasarkan akun G-Mail yang dimiliki. Setelah proses pembuatan akun selesai, proses lain yang dapat dilakukan untuk e-learning adalah posting pengumuman dan pembuatan kelas. Kelas yang dibuat dapat dikelola dengan menggunakan beberapa fitur yaitu tugas, kuis, diskusi, dan materi.

Selain itu, dengan Google Classroom bisa melakukan pengelolaan terhadap kegiatan yang terjadwal dengan menggunakan Google Calender. Materi yang telah diupload juga dapat dikelola di Folder Class di Drive yang terhubung dengan Google Classroom. Akun Guru dapat mengelola orang yang terhubung dengannya di Google Classroom, baik itu antar guru maupun dengan siswanya. Ketika guru memberikan tugas maupun kuis yang memiliki poin, guru tersebut juga dapat memberikan nilai dengan mengelola penilaian sesuai dengan tugas/kuis yang telah dikerjakan oleh siswa. 
Setelah melakukan demo, maka para peserta membuat Classroom dengan semua feature yang tersedia mulai dari pembuatan akun awal, pengumuman, kelas dan pengelolaannya, peniliaan, dan kelola peserta. Selain itu, kelola calendar dan file class di drive. Proses evaluasi akhir dalam pelatihan ini adalah semua peserta dapat melakukan semua aktivitas dalam kelas virtual yang dibuat.

\section{HASIL DAN PEMBAHASAN}

Pengabdian masyarakat ini dilakukan dengan tujuan untuk memberikan kontribusi dalam inovasi pembelajaran menggunakan e-learning. E-learning yang diterapkan adalah menggunakan Google Classroom yang fleksibel dalam penggunaannya. Selain platform gratis, Google Classroom dapat diakses dengan menggunakan personal computer/laptop dan aplikasi smartphone dengan mudah dan cepat. Dimana smartphone merupakan media komunikasi yang sudah sangat populer dan dimiliki oleh hampir semua orang dan kalangan. Dengan demikian, elearning sangat terbantu dan hal yang sangat mungkin untuk diimplementasikan dan dikembangkan.

Proses pengabdian dilakukan dengan mengkaitkan materi $e$-learning dengan pemanfaatan teknologi untuk proses pembelajaran di sekolah. Semua peserta pelatihan akan mengkaitkan Google Classroom dengan akun G-Mailnya. Karena sekolah tidak memiliki email institusi berbasis google, maka e-mail yang digunakan adalah e-mail dari G-Mail itu sendiri.

Penyampaian materi dan pelatihan Google Classroom disampaikan oleh Dosen Universitas Pembangunan Nasional Veteran Yogyakarta. Peserta yang mengikuti adalah semua guru dari MA Raden Fatah Prambanan. Kegiatan yang pelatihan ini dilakukan di Lab. Komputer MA Raden Fatah Prambanan. Masingmasing guru ada yang menggunakan Komputer yang disediakan, tetapi ada juga yang menggunakan laptop sendiri-sendiri dan juga smartphone. Semua aktifitas kegiatan ditunjukkan seperti pada Gambar 2, 3, dan 4. 

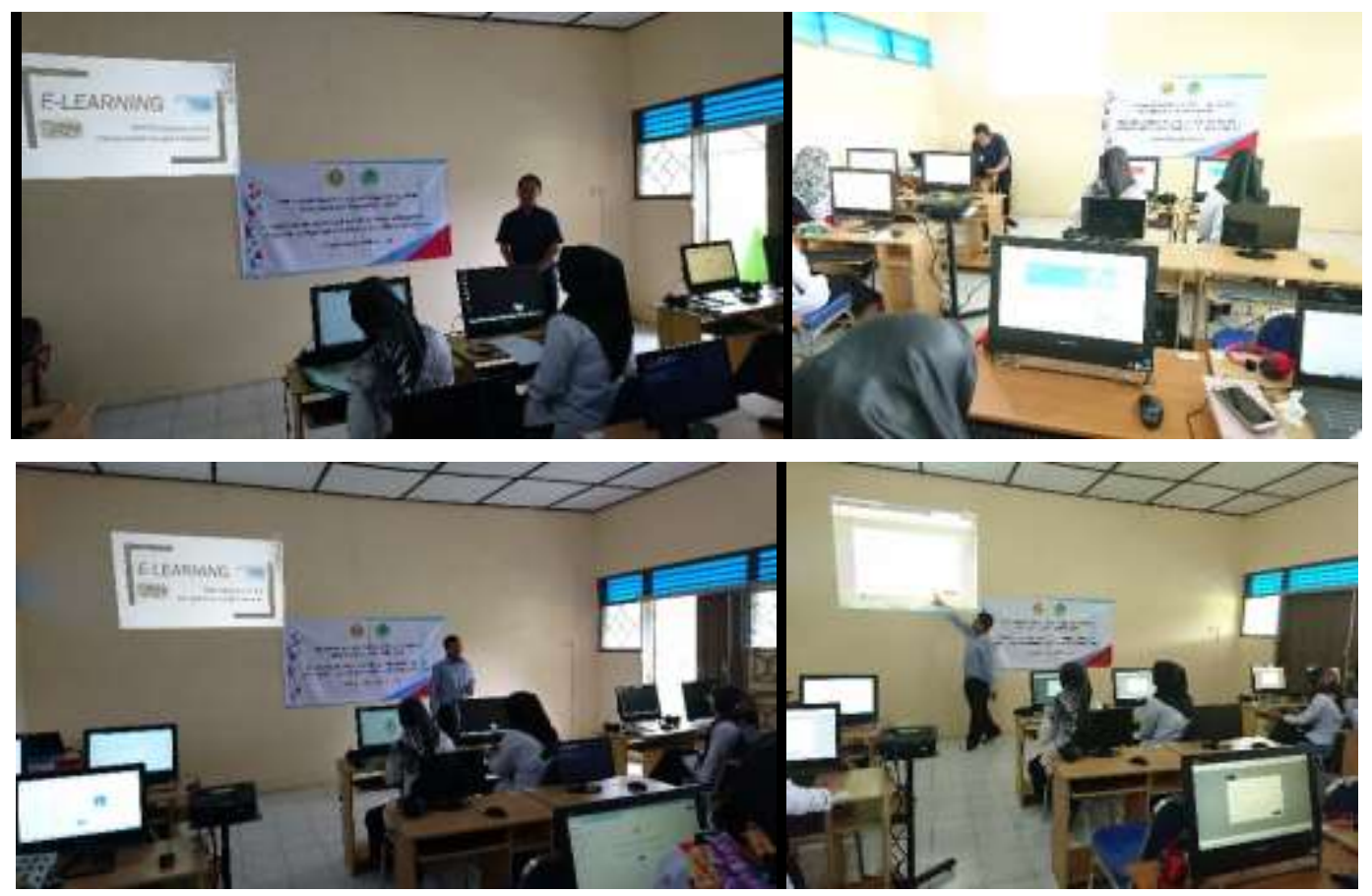

Gambar 2. Penyampaian Materi E-learning dan Google Classroom Kepada Guru MA Raden Fatah Prambanan
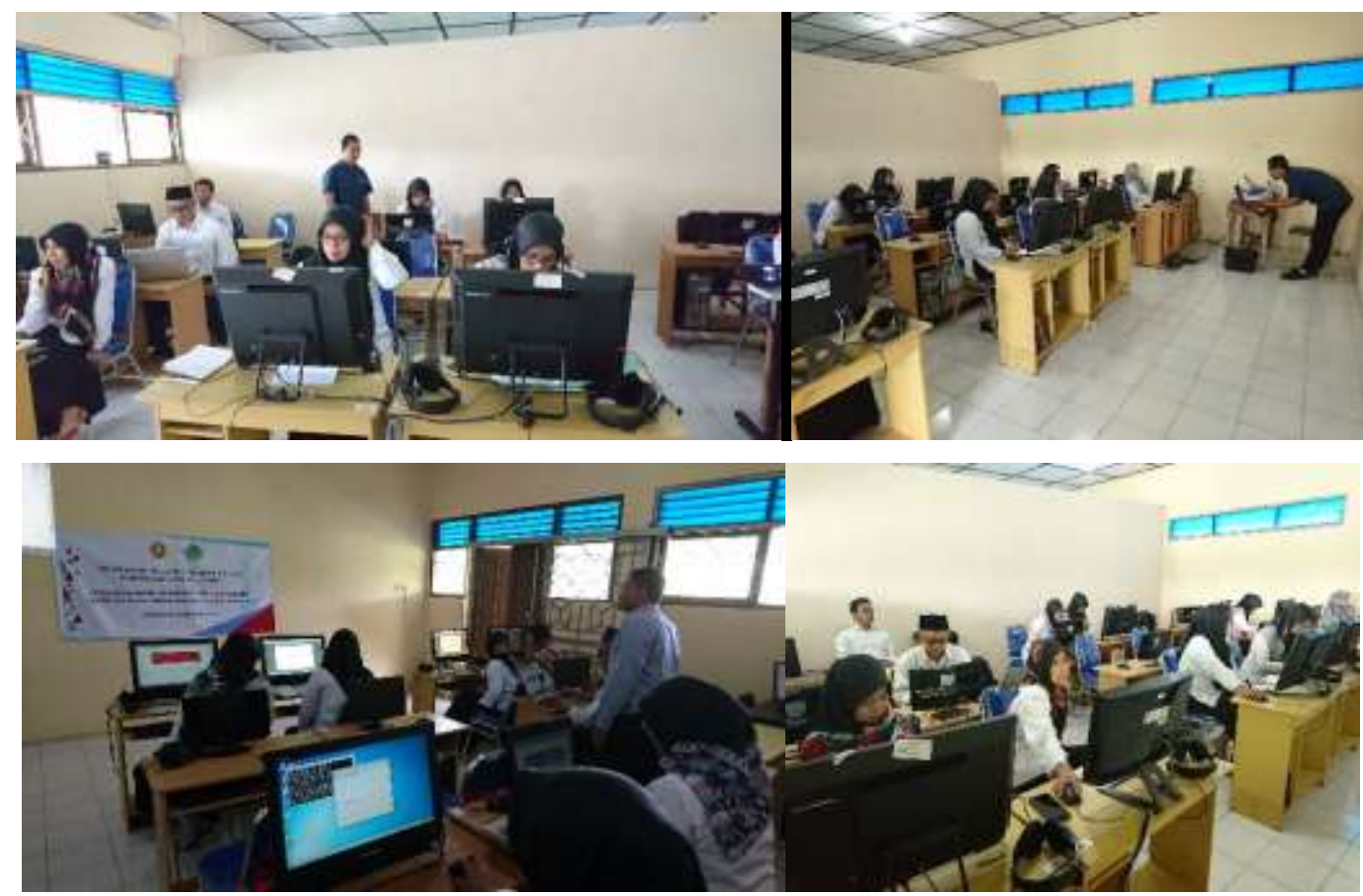

Gambar 3. Praktik Pembuatan dan Penggunaan Google Classroom oleh Guru MA Raden Fatah Prambanan

Gambar 2 dan 3 adalah penyampaian materi e-elarning dan pelatihan Google Classroom. Proses ini dilakukan dalam 2 sesi yaitu sesi penyampaian 
materi kemudian dilangsungkan dengan praktik secara langsung menggunakan Google Classroom. Contoh pembuatan Google Classrom dalam Pengabdian masyarakat ditunjukkan seperti pada Gambar 4.

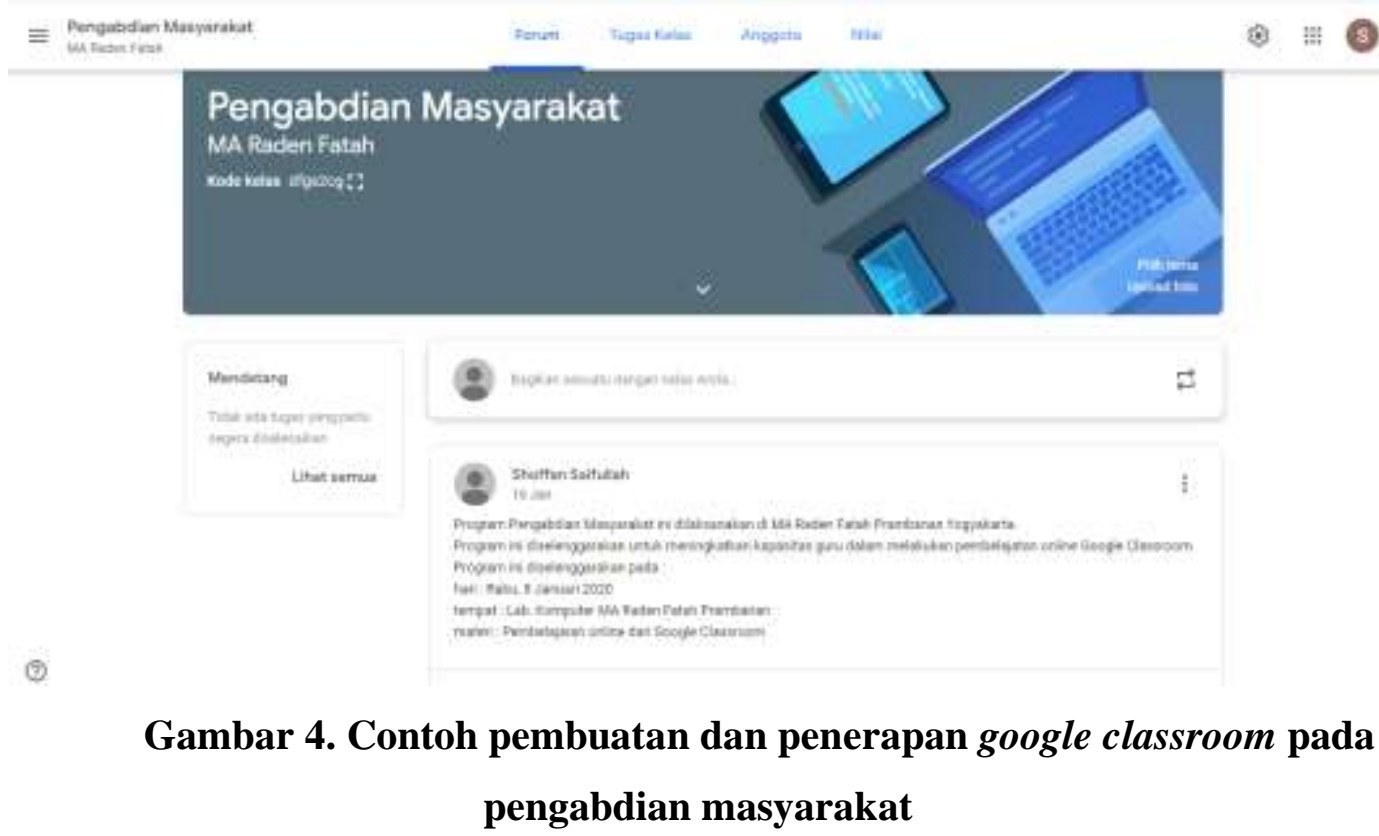

Pada Gambar 4 menunjukkan contoh kelas pengabdian masyarakat yang ada di google classroom. Pada kelas ini terdapat kode kelas, yang mana semua peserta yang mengikuti bisa bergabung dalam kelas ini. Selain itu, terdapat postingan yang sudah terpublikasikan di bagian awal kelas (pengumuman). Selain itu, pada pelatihan ini memberikan pelatihan pengelolaan tugas kelas, anggota dan nilai. Pengelolaan tugas kelas yang dapat dilakukan adalah pengumpulan tugas, kuis, materi, dan diskusi. Dimana meteri-materi yang dishare dapat berupa file, penjelasa, video, gambar. Selain itu, pada bagian kuis bisa dilakukan dengan rentan waktu yang ditentukan dan pertanyaan bisa diacak. Pada kuis tidak hanya berupa pilihan ganda, maupun essai, tapu juga bisa bentuk file yang diupload.

Kegiatan pengabdian ini memperoleh perhatian dan respon dari guru dan kepala sekolah bahwa dalam proses pembelajaran dengan e-learning memberi warna dalam proses belajar mengajar yang ada. Disamping itu, pemanfaatan teknologi ini memberikan konsep yang sangat luas dan terbuka untuk guru dan siswa dalam memperoleh cakrawala pengetahuan yang sangat luas. Sehingga 
proses belajar belajar tidak terfokus hanya di dalam kelas setelah itu selesai. Akan tetapi dapat dilakukan secara bertahap dan bersambung dimana dan kapan saja. Hal ini menjadi pendukung untuk meningkatkan pembelajaran yang tidak hanya bersifat konvensional di dalam kelas, melainkan dengan menggunakan pembelajaran interaktif dengan e-learning, seperti yang disampaikan perbedaan peningkatan pembelajaran konvensional ke e-learning dalam tabel faktor perbedaan yang ada sesuai Tabel 1 .

Tabel 1. Perbandingan pembelajaran konvensional dan e-learning

\begin{tabular}{ccc}
\hline Faktor & Konvensional & E-learning \\
\hline Adanya Pengajar & Bergantung & Tidak Bergantung \\
\hline Pengajar & Sumber Ilmu & Mediator dan Pembimbing \\
\hline Ketersediaan & Terbatas & Mudah diakses \\
\hline Media & Lisan & Audio Visual \\
\hline Mandiri Belajar & Tidak & Ya \\
\hline Ruang dan Waktu & Terbatas & Fleksibel \\
\hline Keaktifan Siswa & Pasif & Aktif \\
\hline Inovatif dan kreatif & Kurang & Meningkat \\
\hline Interaktif & Kurang & Meningkat \\
\hline
\end{tabular}

Berdasarkan pada pelatihan ini, evaluasi yang dilakukan adalah hasil pembuatan dan kelola kelas virtual google classroom. Semua peserta yang hadir dapat membuat semua materi dan demo yang telah dilakukan. Peserta sangat antusias dalam pelaksanaan dan sangat senang, terutama adalah kepala sekolah. Dalam sesi penutupan, hal itu disampaikan oleh kepala sekolah dan menginginkan untuk proses pelatihan tahap lanjut mengenai classroom untuk siswa/pelajar.

Dalam pelaksanaanya masih ada beberapa kendala diantaranya, ketika akses classroom dengan smartphone ada beberapa peserta mengalami kendala seperti aplikasi yang tidak update dan load koneksi yang lambat. Tetapi bisa terselesaikan dengan update dan penggunaan jaringan wifi. Selain itu, ada beberapa peserta yang lupa akun email yang dimilikinya, sehingga harus reset password dan ada juga yang buat email baru. 


\section{SIMPULAN}

Berdasarkan hasil workshop e-learning dengan google classroom yang telah dilakukan dapat disimpulkan bahwa pelatihan/workshop ini dapat memberikan inovasi pembelajaran yang lebih interaktif dengan menggunakan feature-feature yang disediakan google classroom. Selain itu, dapat membagikan materi tidak hanya dalam bentuk materi dokumen atau tulisan, melainkan menggunakan video materi maupun video animasi untuk kasus materi tertentu. Semua peserta (para guru) sangat berantusian dalam pelatihan yang semua dapat dilakukan dengan baik dan diskusi yang aktif dalam setiap kegiatan/sesi dalam Classroom. Dalam pelatihan ini, secara garis besar semua guru mampu menerima dengan baik dan responsif dalam penggunaan google classroom untuk e-learning.

Saran dari kegiatan pengabdian masyarakat ini adalah perlu dilakukan pengawasan dan bimbingan untuk keberlanjutan proses e-larning dengan google classroom. Selain itu, perlu melakukan pelatihan mengenai google classroom untuk siswa sehingga bisa singkron antara guru dan siswa.

\section{UCAPAN TERIMA KASIH}

Penulis mengucapkan terima kasih kepada Universitas Pembangunan Nasional Veteran Yogyakarta yang telah memberi dukungan dan mengijinkan untuk melakukan pengabdian kepada masyarakat ini, khususnya adalah Jurusan Teknik Informatika, Fakultas Teknik Industri. Selain itu, terima kasih juga penulis sampaikan kepada MA Raden Fatah yang telah menerima dan mendukung pelaksanaan pengabdian masyarakat ini.

\section{DAFTAR PUSTAKA}

Efendi, Y., \& Utami, N. (2019). Pengukuran efektifitas pembelajaran menggunakan media e-learning google classroom (SMK Sulthan Muazzamsyah Pekanbaru). In Prosiding Seminar Nasional Computation Technology and its Aplication, 1, 24-27.

Gultom, M. U. (2019). Peran teknologi pendidikan dalam mengembangkan dan meningkatkan keprofesionalan pendidikan di era revolusi industri 4.0.

Husna, H., \& Pinem, K. (2011). Perbedaan hasil belajar siswa antara pengajaran multimedia dengan pengajaran konvensional pada materi iklim global di kelas X SMA N 1 Seruway Kabupaten Aceh Tamiang TP 2009/2010. 
Jurnal geografi, 3(2), 83-93.

Irawan, Y., Susanti, N., \& Triyanto, W. A. (2015). Analisa dan perancangan sistem pembelajaran online (e-learning) pada smk mambaul falah kudus. Simetris: Jurnal Teknik Mesin, Elektro Dan Ilmu Komputer, 6(2), 345-352.

Kristiana, A. I. (2014). Model pembelajaran berbasis e-learning dengan authentic assessment pada mata kuliah aljabar linier prodi pendidikan matematika FKIP Universitas Jember. Kadikma, 5(3).

Lestari, W. P., \& Sujarwo, A. (2018). DevOps: disrupsi pengelolaan ict pendidikan tinggi. In Seminar Nasional Aplikasi Teknologi Informasi (SNATI).

Makarim, N. (2019). Pidato mendikbud Nadiem Makarim pada Upacara bendera peringatan hari guru nasional 2019. Kemendikbud. (Online), (https://www.kemdikbud.go.id/main/blog/2019/11/pidato-mendikbudnadiem-makarim-pada-upacara-bendera-peringatan-hari-guru-nasional2019).

Maunah, B. (2009). Landasan pendidikan. (C. 1 Ed., Ed.). Yogyakarta: Teras.

Montolalu, A. A. (2015). Peranan pemerintah dalam mewujudkan pendidikan wajib belajar di kecamatan Matuari Kota Bitung1. Jurnal Politico, 4(2).

Setiawan, A., Nurlaela, L., Muslim, S., \& Yundra, E. (2019). Pengembangan e learning sebagai media pembelajaran pendidikan vokasi. In Prosiding Seminar Nasional SANTIKA Ke-1 2019 (pp. 52-56).

Wijaya, E. Y., Sudjimat, D. A., \& Nyoto, A. (2016). Transformasi pendidikan abad 21 sebagai tuntutan pengembangan sumber daya manusia di era global. In Prosiding Seminar Nasional Pendidikan Matematika, 1, 263-278). 